\title{
Educational intervention for the prevention of sexually transmitted infections in basic secondary teachers
}

\begin{abstract}
Summary
Introduction: Among the factors that increase sexual infections in adolescence are the early initiation of sexual relations, adolescence is considered a stage of vulnerability and exposure to risky social and/or sexual behaviors that expose them to sexual and reproductive health problems such as unwanted pregnancies and sexually transmitted infections, so it is essential that they are taught in schools comprehensive sexuality education Objective: To assess the effects of educational intervention for the prevention of sexually transmitted infections in teachers of the Antonio José Oviedo Basic Secondary School. San José de las Lajas, Mayabeque during the period: October 2017 to February 2019.
\end{abstract}

Method: A quasi-experimental educational intervention study with a mixed approach to the 40 teachers included in the permanent staff of the center, a survey was applied prior to the intervention that allowed characterizing the teachers according to sociodemographic variables, exploring the level of knowledge, attitudes, perception of risk and beliefs about STIs. 15 work sessions were held and tools were given to facilitate the work on these issues with adolescents. A post-intervention survey was applied to evaluate its effectiveness. Descriptive and inferential statistics (J squared) were applied.

Results: female sex predominated (72.5\%), with ages between 30 and 40 years $(42.5 \%)$, in males the perception of lower risk prevailed compared to females. Knowledge, beliefs, attitudes and perception of risk about STIs were inadequate prior to intervention, after intervention they increased significantly in: $92.5 \%, 65 \%, 77.5 \%$ and $70 \%$ respectively. Conclusions: The educational intervention was effective in contributing to the improvement of comprehensive sexuality education in the school environment.

Keywords: eacThers, adolescence, educational intervention, comprehensive sexuality education, sexually transmitted infections

\author{
Volume II Issue 5 - 2020
}

\author{
Damarys Chacón O’farrill,' Alba Cortes \\ Alfaro $^{2}$ \\ 'First degree specialist in Obstetrics and Gynecology, Second \\ degree specialist in Comprehensive General Medicine, Master in \\ Comprehensive Care for Women, Cuba \\ ${ }^{2}$ Second Degree Specialist in School Hygiene, Master in \\ Epidemiology, Assistant Professor and Researcher, Diploma in \\ STI-HIVIAIDS, National Institute of Hygiene, Epidemiology and \\ Microbiology, Cuba
}

\begin{abstract}
Correspondence: Alba Cortes Alfaro, Second Degree Specialist in School Hygiene, Master in Epidemiology, Assistant Professor and Researcher. Diploma in STI-HIVIAIDS. National Institute of Hygiene, Epidemiology and Microbiology, Havana, Cuba.Email alac@inhem.sld.cu, albaortes@infomed.sld.cu
\end{abstract}

Received: June 26, 2020 | Published: September 22, 2020

\section{Introduction}

In the Sustainable Development Goals (SDG) of the 2030 agenda, numbers 3, 4 and 5 emphasize the protection of human rights and the promotion with gender equality and the empowerment of women and girls, considering it is of vital importance the preservation of sexual and reproductive health. For this, a quality, inclusive and equal education is required. ${ }^{1}$

The Ministries of Education and Public Health, in support of the guidelines directed by the World Health Organization (WHO) and the United Nations Children's Fund (UNICEF), have set the goal of comprehensive training for new generations by creating methodological guidelines for this purpose..$^{2-5}$

Adolescents constitute a vulnerable group because they are in risky situations and do not present skills and tools for the adequate solution of them. Health indicators regarding adolescent pregnancies, the incidence of curable and non-curable Sexually Transmitted Infections (STIs), sexual abuse indicate the increase in the world in these ages. ${ }^{6-9}$

The development of skills through knowledge should be characterized by the assertive dialogue of adolescents, so it is suggested to carry out educational interventions where the school plays a primary role whose methodology is impregnated with their leading role, inclusive, inclusive and participatory character. This is the effectiveness of comprehensive sexuality education (CSE) for the future generation to enjoy a full and responsible sexuality. ${ }^{10-13}$

Adolescence is a well-defined stage in the human life cycle between childhood and adulthood that is characterized by profound biological, psychological and social changes.

Adolescence is defined by the World Health Organization (WHO) as the period of life that elapses between 10 to 19 years. ${ }^{14}$

It is a time of continuous biopsychosocial changes, biological ones are associated with the period of puberty that marks the beginning of adolescence. These changes occur in four directions: anthropometric (relative to weight and height), physiological (neurovegetative alterations), endocrine (increased accelerated production of hormones) and sexual maturation that includes two groups of transformations: primary sexual characteristics, changes structural organs of the reproductive system; and secondary sexual characteristics, traits of sexual maturity, not directly related to the structure of the sexual organs. ${ }^{15}$

Risky behaviors can be sexual or social. The combination of both is frequent and very dangerous for sexual and reproductive health, which is why adolescence is considered a vulnerable group. ${ }^{15}$ 
The main consequence of risky sexual behavior is framed in reproductive damage with the presence of an increase in early pregnancies, abortions and STIs, which in turn, if related to risky social behaviors, can unfortunately culminate in frustration of the life Project. ${ }^{16-18,19}$

The negative increase in health status indicators confirms this. There are global trends that make this population characteristic, such as the fact that the age of initiation of sexual relations is earlier, being around 15 years old. In 2015, adolescent fertility represented $15.2 \%$. Latin America and the Caribbean is the only region where the births of girls under 15years of age increased. Predominating rural areas with adolescent fertility that represents $21 \%$ of total fertility. Every year 44 births are registered in the world for every 1000 girls between the ages of 15 and 19. ${ }^{19.20}$

The World Health Organization (WHO) has estimated that STIs including Acquired Immune Deficiency Virus/Acquired Immune Deficiency Syndrome (HIV/AIDS) constitute, worldwide, the most important cause of disease among men aged 15 to 49 years and the second (after maternal causes) among young women in developing countries. ${ }^{9}$

The adolescent population in Cuba represents $11.92 \%$. 19 . In the 2018 Cuban Statistical Yearbook it is observed that the incidence of Syphilis decreased in relation to 2017 (from 5,088 to 4,706 respectively). Like the incidence of AIDS: with a tendency to decrease, since it was reported: 258 cases and for 2018: 161. However, regarding gonorrhea there was an increase, reporting in 2017, the number of 2,904 cases and for the year 2018: $2953 .^{20}$

This demands greater actions aimed at protecting adolescents in terms of sexuality, as it is a universal right of all people in relation to full, healthy enjoyment and free from all discrimination and social injustice. ${ }^{21,22-24}$

Studies indicate that adolescents can be assertive, that they can discern between right and wrong, and that they can be responsible for their actions, that they must demand and live their rights. ${ }^{25}$

For the adults who accompany them in this stage of life, whether they are teachers and family members, knowing certain characteristics of adolescence can help to understand them, anticipate and manage behaviors and at the government level establish policies and design strategies that favor this social group. ${ }^{26,27}$

WHO has set goals for 2030, including: ending the AIDS epidemics, ensuring universal access to sexual and reproductive health services, including family planning, information and education, and integrating reproductive health into national strategies and programs. ${ }^{1,2,24,28}$

The political will of the Cuban State to promote, protect and guarantee the rights of infants, adolescents and their families as a priority of its social project, is materialized in public policies, programs and projects that are supported by a national legal framework. ${ }^{5}$

There are several deployed with the objective of reducing the incidence of STIs/HIV-AIDS in adolescents, among which is the Sexuality Education Program with a gender and sexual rights approach in the National Education System included in the Resolution Ministerial 139/2011 whose fundamental goal is aimed at promoting the development of healthy, full and responsible sexual behavior in girls and boys, adolescents and young people from the training and development of knowledge, psychosocial skills, values and attitudes that favor the ways behavior and human relationships based on the exercise of sexual rights and gender equality and is inserted in the school curriculum of each level and type of education.Provides extraeducational and extracurricular activities and is also complemented in the family and community. ${ }^{4,5,10}$

Its antecedent is the National Sex Education Program (PRONES), promoted by the National Center for Sexual Education (CENESEX) and lays the foundations for the integration between the Ministries of Education and Public Health and Disciplines within the Social Sciences. ${ }^{15}$

We are forced to think about adolescence to prevent responsibly. The formula is that Comprehensive Sexuality Education (CSE) is needed, thus promoting responsible sexuality. ${ }^{27-29}$

CSE is a teaching / learning process that is supported by competent studies on the cognitive, psychological, physical and social aspects of sexuality, sees sexuality holistically and as part of emotional and social development it gives the opportunity to acquire skills essential for life, as well as developing positive attitudes and values. ${ }^{15}$

Its objective is to provide knowledge based on empirical data, skills, attitudes and values that will empower them to enjoy health, well-being and dignity; establish social and sexual relationships based on respect; analyze how your decisions affect your own well-being and that of others; and understand how to protect and protect their rights throughout their lives. ${ }^{26,31,32}$

A quality HIA, correctly taught and based on gender equality and sexual rights, will provide adolescents with tools for the prevention of sexually transmitted infections, early pregnancies, in self-care, it will work on the formation of basic values, whether they are moral, labor as well as those related to lifestyles. ${ }^{31,32}$

To achieve better results and effectively face the problems related to sexuality in adolescents, intersectorality and interdisciplinarity are essential. We are talking about the integration of programs designed for adolescents and young people either by pedagogical institutes and school health services without forgetting to add disciplines such as sociology, psychology, philosophy and legal sciences. ${ }^{25-27}$

School plays great importance then as a socializing agent, where adolescents spend a large part of their days. It is there where teachers interact directly with them and impart comprehensive knowledge of sexuality to them either through the curricular pathway as a direct part of their lives. ${ }^{32}$

The Cuban curricular educational conception assumes the process of sexuality education with a gender and sexual rights approach from a comprehensive, transversalized perspective that promotes an active educational process. ${ }^{5,32}$

To achieve the cognitive incorporation of sexuality, the acquisition of correct attitudes and beliefs with a high perception of risk, educational intervention strategies relevant to this age should be drawn. ${ }^{3,4}$ The present study allows us to approach an educational intervention for the prevention of sexually transmitted infections that allows us to have tools for subsequent work with adolescents.

\section{Method}

A quasi-experimental educational intervention study was carried out without a control group with a quantitative-qualitative approach in teachers of the Antonio José Oviedo Urban Basic Secondary School, of the Municipality of San José de las Lajas, in the period from October 2017 to February 2017. 2019. The study universe was represented by 40 teachers who were part of the permanent staff of the School. 
In the development of the educational intervention, 15 sessions were held where workshops were given that addressed topics such as the most frequent sexually transmitted infections (STIs), those that are curable and incurable, predominant manifestations, routes of transmission, proper use of condoms, among others. Participatory and evaluation techniques were also applied in each session.

To carry out the intervention, the following were taken into account: Sexuality Education Program with a Gender and Sexual Rights Approach in the national education system, Ministerial Resolution No. 139/2011 and the methodological guidelines of the Ministry of Education (MINED) and of the Ministry of Public Health (MINSAP), prioritized in this social historical moment where youth has a fundamental role. ${ }^{3-5}$

The study was carried out from the theoretical methodological triangulation method that combines the qualitative and quantitative approaches of the Methodology of Investigation. ${ }^{33}$
The qualitative approach was related to the data provided by means of the semi-structured interview carried out with the teachers during the intervention and which allowed the understanding of the phenomenon in all its dimensions, as well as the experiences of the subject around the process.

For the quantitative study, a questionnaire on Sexually Transmitted Infections from the Department of School Health of the National Institute of Hygiene, Epidemiology and Microbiology (INHEM) was used, authored by Dr. Cortés, which measures knowledge, attitudes, beliefs and perception of risk of adolescents about STIs, measuring the phenomenon with the use of descriptive and inferential statistical methods (Chi square) that allowed us to analyze reality objectively. 3,33

The presentation of the results are presented in table forms for better understanding. For this research, the basic principles of ethics were taken into account (Table 1).

Table I Operationalization of the variables

\begin{tabular}{|c|c|c|c|c|}
\hline Variable sociodemographic & Type of variable & Scale & Description & Indicator \\
\hline \multirow[t]{2}{*}{ Sex } & \multirow[t]{2}{*}{$\begin{array}{l}\text { Qualitative nominal } \\
\text { dichotomous }\end{array}$} & Male & \multirow[t]{2}{*}{$\begin{array}{l}\text { According to } \\
\text { phenotype }\end{array}$} & \multirow[t]{2}{*}{$\begin{array}{l}\text { Absolute } \\
\text { frequency } \\
\text { and } \\
\text { percentage }\end{array}$} \\
\hline & & Female & & \\
\hline Age & Discrete quantitative & $\begin{array}{l}22-29 \text { years } \\
30-40 \text { years } \\
41 \text { years and over }\end{array}$ & $\begin{array}{l}\text { According to } \\
\text { completed years }\end{array}$ & $\begin{array}{l}\text { Absolute } \\
\text { frequency } \\
\text { and } \\
\text { percentage }\end{array}$ \\
\hline Level of education & Discrete quantitative & $\begin{array}{l}\text { Middle Technician } \\
12 \text { degrees } \\
\text { academic }\end{array}$ & $\begin{array}{l}\text { According to the } \\
\text { level of study } \\
\text { achieved }\end{array}$ & $\begin{array}{l}\text { Absolute } \\
\text { frequency } \\
\text { and } \\
\text { percentage }\end{array}$ \\
\hline Cognitive variables & & Adequate: from 9 correct answers & & \\
\hline Identification of more frequent STIs. & $\begin{array}{l}\text { Qualitative nominal } \\
\text { dichotomous }\end{array}$ & $\begin{array}{l}\geq 75 \% \\
\text { Inadequate: (less than established) } \\
\text { Total minimum points: } 18\end{array}$ & $\begin{array}{l}\text { According to the } \\
\text { knowledge about } \\
\text { the etiology of } \\
\text { STIs. }\end{array}$ & $\begin{array}{l}\text { Absolute } \\
\text { frequency } \\
\text { and } \\
\text { percentage }\end{array}$ \\
\hline Knowledge about curable STls. & $\begin{array}{l}\text { Qualitative nominal } \\
\text { dichotomous }\end{array}$ & $\begin{array}{l}\text { Adequate: } \\
\text { It cures: } \\
\geq 3 \text { responses } \\
\text { correct } \\
-75 \% \\
\text { It is not cured: } \\
\geq 2 \text { correct answers } \\
-66 \% \\
\text { Inadequate: less than established. } \\
\text { Total minimum points: } \\
6 \text { points heals } \\
4 \text { points does not heal }\end{array}$ & $\begin{array}{l}\text { About the } \\
\text { knowledge they } \\
\text { have regarding } \\
\text { the currently } \\
\text { available } \\
\text { therapeutics for } \\
\text { the eradication } \\
\text { of the causative } \\
\text { agent. }\end{array}$ & $\begin{array}{l}\text { Absolute } \\
\text { frequency } \\
\text { and } \\
\text { percentage }\end{array}$ \\
\hline
\end{tabular}


Table Continued...

\begin{tabular}{|c|c|c|c|c|}
\hline Variable sociodemographic & Type of variable & Scale & Description & Indicator \\
\hline $\begin{array}{l}\text { Knowledge about the prevention of } \\
\text { STIs. }\end{array}$ & $\begin{array}{l}\text { Qualitative nominal } \\
\text { dichotomous }\end{array}$ & $\begin{array}{l}\geq 2 \text { suitable } \\
\text { Correct answers }(66 \%) \\
\text { Inadequate: less than established. } \\
\text { Total minimum points: } 4\end{array}$ & $\begin{array}{l}\text { Knowledge of } \\
\text { measures aimed } \\
\text { at avoiding the } \\
\text { initial appearance } \\
\text { of an STI-HIV / } \\
\text { AIDS }\end{array}$ & $\begin{array}{l}\text { Absolute } \\
\text { frequency } \\
\text { and } \\
\text { percentage }\end{array}$ \\
\hline $\begin{array}{l}\text { Knowledge of behaviors } \\
\text { risky towards STIs. }\end{array}$ & $\begin{array}{l}\text { Qualitative nominal } \\
\text { dichotomous }\end{array}$ & $\begin{array}{l}\geq 9 \text { adequate } \\
\text { With correct answers (69\%) } \\
\text { Inadequate: less than established. } \\
\text { Total minimum points: } 18\end{array}$ & $\begin{array}{l}\text { Specific form of } \\
\text { behavior known } \\
\text { to be related } \\
\text { to increased } \\
\text { susceptibility } \\
\text { for a specific } \\
\text { disease based on } \\
\text { epidemiological } \\
\text { and social data. }\end{array}$ & $\begin{array}{l}\text { Absolute } \\
\text { frequency } \\
\text { and } \\
\text { percentage }\end{array}$ \\
\hline $\begin{array}{l}\text { Knowledge of the transmission routes } \\
\text { of STI-HIV / AIDS }\end{array}$ & $\begin{array}{l}\text { Qualitative nominal } \\
\text { dichotomous }\end{array}$ & $\begin{array}{l}\geq 6 \text { suitable } \\
\text { With correct answers (66\%) } \\
\text { Inadequate: less than established. } \\
\text { Total minimum points: } 12\end{array}$ & $\begin{array}{l}\text { According to } \\
\text { your knowledge } \\
\text { of the different } \\
\text { ways in which } \\
\text { a person can } \\
\text { acquire STI-HIV } \\
\text { / AIDS. }\end{array}$ & $\begin{array}{l}\text { Absolute } \\
\text { frequency } \\
\text { and } \\
\text { percentage }\end{array}$ \\
\hline $\begin{array}{l}\text { Clinical manifestations that may } \\
\text { indicate the existence of } \\
\text { STI- HIV / AIDS }\end{array}$ & $\begin{array}{l}\text { Qualitative nominal } \\
\text { dichotomous }\end{array}$ & $\begin{array}{l}\text { adequate } \\
\text { Correct answers } 73 \% \\
\text { Inadequate: less than established. } \\
\text { Total minimum points: } 22\end{array}$ & $\begin{array}{l}\text { According to } \\
\text { the knowledge } \\
\text { of the main } \\
\text { symptoms or } \\
\text { signs that show } \\
\text { the existence of } \\
\text { the STI- HIV / } \\
\text { AIDS. }\end{array}$ & $\begin{array}{l}\text { Absolute } \\
\text { frequency } \\
\text { and } \\
\text { percentage }\end{array}$ \\
\hline $\begin{array}{l}\text { Consequences of contracting STI-HIV } \\
\text { / AIDS. }\end{array}$ & $\begin{array}{l}\text { Qualitative nominal } \\
\text { dichotomous }\end{array}$ & $\begin{array}{l}\geq 10 \\
\text { adequate } \\
\text { Correct answers: } 76 \% \\
\text { Inadequate: less than established. } \\
\text { Total minimum points: } 20\end{array}$ & $\begin{array}{l}\text { It refers to } \\
\text { the event or } \\
\text { consequent } \\
\text { illnesses of } \\
\text { contracting STI- } \\
\text { HIV / AIDS. }\end{array}$ & $\begin{array}{l}\text { Absolute } \\
\text { frequency } \\
\text { and } \\
\text { percentage }\end{array}$ \\
\hline Knowledge about condom use. & $\begin{array}{l}\text { Qualitative nominal } \\
\text { dichotomous }\end{array}$ & $\begin{array}{l}\geq 3 \\
\text { adequate } \\
\text { Correct answers: } 33 \% \\
\text { Inadequate: less than established: } \\
44 \% \\
\text { Total minimum points: } 12\end{array}$ & $\begin{array}{l}\text { According to } \\
\text { knowledge about } \\
\text { condom use } \\
\text { in relation to } \\
\text { sexual practice. }\end{array}$ & $\begin{array}{l}\text { Absolute } \\
\text { frequency } \\
\text { and } \\
\text { percentage }\end{array}$ \\
\hline Knowledge of HIV transmissibility & $\begin{array}{l}\text { Qualitative nominal } \\
\text { dichotomous }\end{array}$ & $\begin{array}{l}\text { Yes:Adequate (100\%) } \\
\text { Inadequate: } \\
\text { Not }\end{array}$ & $\begin{array}{l}\text { In relation to } \\
\text { transmissibility } \\
\text { according to the } \\
\text { stages in which } \\
\text { the person living } \\
\text { with the virus } \\
\text { (PLHIV) passes }\end{array}$ & $\begin{array}{l}\text { Absolute } \\
\text { frequency } \\
\text { and } \\
\text { percentage }\end{array}$ \\
\hline Know when to use a condom & $\begin{array}{l}\text { Qualitative nominal } \\
\text { dichotomous }\end{array}$ & Adequate (I00\%): answer 2 & $\begin{array}{l}\text { Related to the } \\
\text { correct form in } \\
\text { terms of when } \\
\text { to put on the } \\
\text { condom. }\end{array}$ & $\begin{array}{l}\text { Absolute } \\
\text { frequency } \\
\text { and } \\
\text { percentage }\end{array}$ \\
\hline
\end{tabular}




\begin{tabular}{|c|c|c|c|c|}
\hline Variable sociodemographic & Type of variable & Scale & Description & Indicator \\
\hline Knowledge about condom safety & $\begin{array}{l}\text { Qualitative nominal } \\
\text { dichotomous }\end{array}$ & $\begin{array}{l}\text { No:Adequate (100\%) } \\
\text { Inadequate: } \\
\text { Yes }\end{array}$ & $\begin{array}{l}\text { Related to the } \\
\text { myth of its use }\end{array}$ & $\begin{array}{l}\text { Absolute } \\
\text { frequency } \\
\text { and } \\
\text { percentage }\end{array}$ \\
\hline $\begin{array}{l}\text { Perception of risk of contracting STI- } \\
\text { HIV / AIDS }\end{array}$ & $\begin{array}{l}\text { Qualitative nominal } \\
\text { dichotomous }\end{array}$ & $\begin{array}{l}\text { Adequate:Yes: Score: } 3 \text { points } \\
\text { Total correct score: } 24 \\
\text { Inadequate No: I point. }\end{array}$ & $\begin{array}{l}\text { Vulnerability } \\
\text { perceived by } \\
\text { the person } \\
\text { to consider } \\
\text { themselves at } \\
\text { risk or not of } \\
\text { becoming ill with } \\
\text { STI-HIV / AIDS }\end{array}$ & $\begin{array}{l}\text { Absolute } \\
\text { frequency } \\
\text { and } \\
\text { percentage }\end{array}$ \\
\hline Modification of attitude. & $\begin{array}{l}\text { Qualitative nominal } \\
\text { dichotomous }\end{array}$ & $\begin{array}{l}\text { questions } 22,29 \text { and } 30 \text { adequate } \\
\text { considerations: } 3 \text { points } \\
\text { Inappropriate: no value }\end{array}$ & $\begin{array}{l}\text { The ability of } \\
\text { the person to } \\
\text { transform their } \\
\text { sexual behavior } \\
\text { and attitude } \\
\text { towards people } \\
\text { with STI-HIV } \\
\text { / AIDS in } \\
\text { dependence on } \\
\text { knowledge }\end{array}$ & $\begin{array}{l}\text { Absolute } \\
\text { frequency } \\
\text { and } \\
\text { percentage }\end{array}$ \\
\hline Beliefs about STI-HIV / AIDS & $\begin{array}{l}\text { Qualitative nominal } \\
\text { dichotomous }\end{array}$ & $\begin{array}{l}\text { Adequate:Yes: Score: } 3 \text { points } \\
\text { Total correct score: } 6 \\
\text { Inadequate No and I don't know: I } \\
\text { point }\end{array}$ & $\begin{array}{l}\text { Positive changes } \\
\text { in relation to } \\
\text { people with STI- } \\
\text { HIV / AIDS }\end{array}$ & $\begin{array}{l}\text { Absolute } \\
\text { frequency } \\
\text { and } \\
\text { percentage }\end{array}$ \\
\hline
\end{tabular}

In Table 2, it is observed that the predominant sex was female in $72.5 \%$ and the predominant age in the sample is between 30 and 40 years old for $42.5 \%$.

The large percentage of women incorporated into the educational sector is related to gender, which refers to the set of attributes, attributions, characteristics assigned to sex and which has several dimensions: Biological, Social, economic, subjective and political and that with the development of society has become the Sexual Division of Labor. ${ }^{34}$

Several studies by sociologists and anthropologists suggest that the different participation of men and women in social, economic, and political institutions, among others, has to do with the attitudes, values and expectations that a given society conceptualizes as feminine or masculine. ${ }^{34,35}$
The content and traditional valuations that are expressed in the patriarchal ideology present both in individuals and in human groups and that are transmitted to other people and groups through socialization in processes of human interaction and communication are evident. The different institutions and groups with which people interact from the moment of birth and throughout their lives come into play here. ${ }^{36-38}$

It is shown that the level of education of the teachers (Table 3) in its highest percentage belong to the category of Professional Medium Technician for $55 \%$, which generally reflects the capacity for their work performance in front of the students.

In the research carried out, we appreciate that both sexes presented an inadequate perception of risk before the intervention, but in a lower percentage in men $(10 \%)$ and after it, they increased significantly in both sexes. Table 4

Table 2 Age and sex of the teachers

\begin{tabular}{lllllllll}
\hline Ages & \multicolumn{1}{c}{ Sex } & $20-29$ & & $30-40$ & 40 & & Total & \\
\cline { 2 - 8 } & Not & $\%$ & Not & $\%$ & Not & $\%$ & Not & $\%$ \\
\hline Male & 4 & 10 & 5 & 12.5 & two & 5 & eleven & 27.5 \\
Female & 6 & fifteen & 12 & 30 & eleven & 27.5 & 29 & 72.5 \\
TOTAL & 10 & 25 & 17 & 42.5 & 13 & 32.5 & 40 & 100 \\
\hline
\end{tabular}


Table 3 Distribution of teachers according to schooling

\begin{tabular}{lll}
\hline Level of schooling & & \\
\hline Scholarship & Number & Percent \\
\hline 12 degrees & 12 & 30 \\
Professional average technician & 22 & 55 \\
academic & 6 & fifteen \\
Total & 40 & 100 \\
\hline
\end{tabular}

Table 4 Relationship between risk perception and sex

\begin{tabular}{lllll}
\hline \multicolumn{2}{l}{ Risk perception } & & \\
\hline \multirow{2}{*}{ Sex } & \multicolumn{2}{l}{ Before the intervention } & \multicolumn{2}{l}{ After the intervention } \\
\cline { 2 - 5 } & Not & $\%$ & Not & $\%$ \\
\hline Male & 4 & 10 & 8 & twenty \\
Female & eleven & 27.5 & twenty & fifty \\
Total & fifteen & 37.5 & 28 & 70 \\
\hline
\end{tabular}

The perception of risk is understood as the vulnerability perceived by the person to consider themselves at risk or not of getting sick The common citizen, unaware of how some biological agents that promote STIs act, will assume that when faced with risky behaviors, symptoms will appear immediately if they have been infected; will continue to assume those risks by not being able to verify ailments as a result of their actions. This situation leads him to get used to risk, leading him to think, in an excess of confidence, "nothing is wrong with me" or "that will not happen to me". 39,40
Authors like Salazar amador ${ }^{44}$ argue that this is related to the cultural concepts of masculinity that exist in Cuba fostered under the influence of a patriarchal society, in which men tend to have a low perception of risk: with frequent partner changes, they are more reluctant to use the It is difficult for women to ask them to use a condom, since they consider that by doing so their partners may think that they are "easy women, who have a very active and unstable sexual life", among others that far from bringing them closer, distances real goal is to protect yourself. ${ }^{35,36,41,42}$

Educators play an important role as agents of change in the field of sexuality for young people of the future. Teachers are recognized as a valid source of information for adolescents and become an excellent strategy to educate them on issues of sexuality. It is important that sexual instruction is carried out during adolescence of basic education, therefore, a valid way of access to this population is through the instruction of their own educators, which is of vital importance given that students spend the most number of hours of the day in their educational centers. State policies that support teacher training in sex education and STIs, a broad understanding of the social context in which children develop, and a strategic partnership with the school, determines the success or failure of a sexual instruction program, as well as facilitating dialogue within the family nucleus and the school. $^{2-6,10,15,21,23,27}$ In Table 5 the comparison of the knowledge, risk perception, attitudes and beliefs variables. In the knowledge variable, subvariables were measured such as identification of curable and incurable STIs, identification of clinical manifestations and aspects related to condom use. It should be noted that although before the intervention it was found that these were inadequate $(27.5 \%)$, later the expected results of significant increase were obtained (92.5\%), thus coinciding with other educational interventions already carried out in Cuba. ${ }^{43,44}$ Likewise, they facilitate dialogue within the family nucleus and the school. ${ }^{2-6,10,15,21,23,27}$

Table 5 Comparison of the variables studied before and after the educational intervention

\begin{tabular}{llllllll}
\hline \multicolumn{2}{l}{ Comparison of the study variables } \\
\cline { 1 - 5 } Variables studied & \multicolumn{2}{l}{ Start of the study } & \multicolumn{2}{l}{ Final of the study } & \multirow{2}{*}{ Value of $\mathbf{X}^{2}$} & P value \\
\cline { 2 - 5 } & Not & $\%$ & Not & $\%$ & & \\
\hline Knowledge & eleven & 27.5 & 37 & 92.5 & 352,083 & 0.00015 \\
Risk Perception & fifteen & 37.5 & 28 & 70 & 8.4978 & 0.0036 \\
Attitudes & 13 & 32.5 & 31 & 77.5 & 16.3636 & 0.003 \\
Beliefs & 19 & 47.5 & 26 & 65 & 22,029 & 0.0001 \\
\hline
\end{tabular}

P. 0.2359

In international research such as the one carried out in Ecuador by Teodoro Barros entitled "A model of primary prevention of sexually transmitted diseases and HIV/AIDS in adolescents", the existing difficulties in terms of knowledge about STIs in teachers are evident. To the need to contribute to the development of educational tools for the prevention of STIs. ${ }^{45}$

After home, schools are the most important places in charge of adolescent development. School health education can help teens adopt attitudes and behaviors that support their overall health and well-being, and even those that reduce the risk of STIs and the risk of pregnancy.

Before the intervention, attitudes and beliefs were $32.5 \%$ and $47.5 \%$, which with the educational intervention increased by $77.5 \%$ and $65 \%$ respectively. The research carried out coincides with the study carried out by Dr. Alba Cortes Alfaro where she carries out educational intervention in teachers that resulted in facilitators for adolescents and the variables attitude, perception of risk and beliefs increased significantly post intervention. ${ }^{39}$

Although the attitudes showed better results after the intervention $(77.5 \%)$, we confirm that they are more complex in their process since they need interventions of greater durability in time to take their modifications as true and significant. ${ }^{39}$ Since the fact of That a person acquires a certain level of knowledge does not mean that they change their attitude towards dealing with HIV-positive people, although in Cuban society solidarity and humanism prevail as distinctive characters in a general way. 
In the semi-structured interview carried out with the teachers prior to the educational intervention, they considered that adolescents present risks to acquire STI-HIV/AIDS and they do not believe them prepared to have sexual relations or suitable for responsible motherhood and fatherhood.

Most responded that they did not know how to stimulate condom use in adolescence, some of them referred to the importance of actions carried out by health personnel in schools as measures to reduce the risk of contracting STIs in adolescence.

They affirm that information and communication par excellence, turns out to be an efficient way of producing knowledge and through it the spread of STIs and HIV can be prevented. It is a professional way of providing help, if one takes into account that adolescents can express their feelings, their fears and fears; it can also generate suitable behavior alternatives.

In relation to the values that they take into account in the experience of sexuality, the teachers express that they must work on love, fidelity, trust, respect, honesty, sincerity and freedom of decision. Regarding the attitudes that the adolescent takes into account to assume with responsibility.

Regarding attitudes to assume a responsible sexuality, they refer to respecting people without discriminating their sex, identity and sexual orientation; not feel pressure to have sex, decide freely and voluntarily about it, have scientific information about STIs - HIV/AIDS.

Ministerial Resolution 139/2011 regarding work with adolescents is a necessary result to promote and encourage the participation of men and women, in full equality, in all responsibilities of family life, including family planning and prevention of diseases, in this case, STIs; that special efforts should be made to insist on man's part of responsibility and promote his active participation in responsible fatherhood, as well as responsible sexual and reproductive behavior This could be achieved through information, education and communication.

Post-intervention, in addition to the knowledge acquired, which favored an increase in the perception of risk, with positive changes in attitudes and beliefs, teachers acquired tools for curricular work with students.

\section{General integration of results}

The methodological triangulation allows to appreciate correspondence between the results expressed in the quantitativequalitative techniques.

These show us teachers with adequate educational levels to work with adolescents, to be aware that adolescence is considered a social and sexual risk group and that despite knowing the state regulations and having the program in mind of Sexuality Education with a Gender and Sexual Rights Approach in the National Education System, initially possessed inadequate knowledge about STIs, which made it difficult for them to use and practice the implicit dimensions. Once the intervention was carried out, if they had tools for this work, therefore communication between them was favored

\section{Conclusion}

The female sex predominates in the work of the school, with ages of 30-40years and with levels of education of medium technicians.
Initially, they had inadequate knowledge, attitudes, beliefs and perception of risk to STI-HIV/AIDS.

By increasing the level of knowledge in teachers about STIs, the state of risk perception, attitudes and beliefs are improved.

The implementation of the educational intervention with The preventive-educational approach in teachers is considered effective in improving the process of comprehensive sexuality education with a gender and sexual rights approach and provides them with tools for communication and favoring prevention in favor of responsible sexual reproductive health.

\section{Acknowledgments}

None.

\section{Funding}

None.

\section{Conflicts of interest}

All authors declare that they have no competing interests.

\section{References}

1. Draft final document of the United Nations summit for the approval of the post-2015 development agenda. PAHO/WHO.

2. QUIEN. WHO Recommendations on adolescent sexual and reproductive health and rights. 2018

3. Cortés Alfaro A, García Roché R, Duque Santana I, et al. Methodology for the prevention of STI-HIV/AIDS in adolescents and young people. National Center for STI/HIV/AIDS Prevention. Editorial Lazo Adentro. Havana; 2006. ISBN 959-283-013-4.

4. Torres Cueto MA. Sexuality education and prevention of STIs and HIV/ AIDS from the gender, rights and sociocultural perspectives. Basic secondary education, pre-university, professional and adult technique. Havana: Ministry of Education. [Internet] 2011.

5. Sexuality education program with a gender and sexual rights approach in the national education system. Ministerial Resolution No. 139/2011. Ministry of Education, Havana; 2012.

6. Araujo Gonzales R. Vulnerability and health risk: Two concomitant concepts? News in population. Center for Demographic Studies. ISSN: 2308- 2984 RNPS: 0638 No 9 74-79. 2015.

7. Díaz Machado A, Cruz Sánchez F, León Reyes S, et al. Adolescence in Cuba. Indicators of your health status, 2016. Rev ADOLECA. 2017.

8. World Health Organization. Sexually transmitted infections. 2016.

9. WHO. Adolescents: health risks and solutions. Geneva: WHO; 2017.

10. Guidelines of the economic and social policy of the party and the revolution. Havana: VI Congress of the Party; 2011.

11. Benavides K, Alfaro DP. Teaching mediation strategies for education on sexually transmitted infections in adolescents. Rev Nursing Current in Costa Rica. 2016

12. Márquez F. Theoretical framework of promotion and education for health.

13. Education at the service of peoples and the planet: Creating sustainable futures for all. 2016

14. Cruz Sánchez F, Rodríguez Alonso B, Alonso Uría UK. Childcare in adolescence. Havana: Ministry of Public Health; 2014. ISBN: 978-959283-108-7. 
15. Guerrero Borrego N, Pérez Enríquez M. Comprehensive education of sexuality in childhood, adolescence and youth. Conceptual approach. In: Guerrero Borrego N, editor. Reflections and views on sexuality in childhood, adolescence and youth. Havana: CENESEX; 2016. ISBN: 978-959-7187-86-8.

16. Casales J. The Attitudes of Personality. In: Kuzmin E. Selection of readings in social psychology. Havana, Cuba: University of Havana; 1982:180-186.

17. Collective of Authors. The actitudes. Series of social psychology materials. Havana, Cuba: MINED; 1974.

18. UNICEF. Progress for children 2012: A report on adolescents. Join for childhood; 2012.

19. Morales Ojeda R. Universal health coverage. Cuban experience; 2015.

20. Ministry of public health. Statistical yearbook of health 2018. Cuba.

21. Castro Espín M, Rivero Pino R. Government responsibility and comprehensive sexuality education in Cuba. Havana: CENESEX; 2015. ISBN: 978-959-7187-72-1.

22. Casanova Fabelo L, Estevez Garcia KR. Cuba on the post-2015 educational agenda. Rev Estudio. 2016(20):28-40.

23. Comprehensive sexuality education. 2016.

24. High Level Working Group for the CIPD. Rights, dignity and health for all. Priorities for the post-2015 development agenda.

25. Calero Yera Esmeralda, Rodríguez Roura Sandra, Trumbull Jorlen Aniocha. Approach to sexuality in adolescence. Rev Hum Med. 2017;17(3):577-592.

26. Why is comprehensive sexuality education important? 2016.

27. Gómez Suárez RT, Díaz Álvarez M, Sainz Rivero ER, et al. Educational actions on aspects of sexuality aimed at adolescents. Cuban Journal of Public Health. 2015;41(1):146-152.

28. United Nations. Transforming our world: the 2030 Agenda for Sustainable Development. 2015.

29. International Technical Guidelines on Sexuality Education. An evidencebased approach for schools, teachers, and health educators. 2010.

30. UNESCO. Reflections on the evaluation of educational quality in Latin America and the Caribbean. 2008.

31. Pan American Health Organization. Strengthening of regional initiative for health-promoting schools: strategies and lines of action 2003-2012. 2003.
32. Roca Zayas AA. Comprehensive education of sexuality with a gender and law approach in the educational system. Havana: Ministry of Education; 2015. ISBN: 978- 959-18-1113-4.

33. Hernández Sampieri R, Fernández-Collado C, Baptita Lucio P. Research methodology. 6th edn. Mexico: Editorial MCgraw-Hill Interamericana; 2014.

34. Bosch E. History of misogyny. Ed Anthropos. Spain: University of the Balearic Islands; 1999.

35. Fuller N. Warmi Sheets No.8. Feminist Thought and Studies on Male Gender Identity. Barcelona Spain: University of Barcelona; 1997.

36. Montecino S. And Rebolledo L. Concepts of gender and development. Becoming of a translation: from woman to gender or from universal to particular. Chile: Universidad de Chile; 1996.

37. Lagarde M. Gender and Feminism. Human development and democracy. Hours and Hours. Madrid Spain; 1996.

38. Lamas M. Feminist anthropology and the category "gender" of X in Gender: the cultural construction of sexual difference. PUEG; 1996:97111.

39. Cortés Alfaro A, García Roche R, Lazo González Z, et al. Intervention in knowledge, beliefs and perception of risk about sexually transmitted infections and HIV/AIDS. Medicentro Electrónica. 2014;49(1).

40. Collective of authors. Manual for family doctors on STI/HIV/AIDS. MINSAP. Cuba: City of Havana; 2003. 111 p.

41. Salazar Amador SG. The male health disadvantage. Masculinities and paternities in Cuba. Editorial CENESEX; 2015:71-72.

42. Rivero Pino R. Masculinities. Historical-social essay. Editorial CENESEX; 2016:229-232.

43. Ortiz Sánchez NL. Sexually transmitted infections: educational intervention in adolescents from a vocational technical school. Medwave. 2014;14(1):e5891.

44. Ortiz Sánchez NL, Rodríguez González DA, Vázquez Lugo M, et al. Educational intervention on sexually transmitted infections in adolescents. $2015 ; 37(5)$.

45. Teodoro B. A model of primary prevention of sexually transmitted diseases and HIV/AIDS in adolescents. Santo Domingo de los Colorados. Ecuador. 